\author{
JAKUB SKIBIŃSKI $^{1}$, PAULINA PRUSZKOWSKA-PRZYBYLSKA ${ }^{2}$ \\ ${ }^{1}$ Student kierunku Mikrobiologia \\ Wydział Biologii i Ochrony Środowiska \\ Uniwersytet Łódzki \\ Banacha 12/16, 90-237 Łódź \\ ${ }^{2}$ Katedra Antropologii \\ Wydział Biologii $i$ Ochrony Środowiska \\ Uniwersytet Łódzki \\ Banacha 12/16, 90-237 Łódź \\ E-mail: jk.skibinski@gmail.com \\ paulina.pruszkowska@biol.uni.lodz.pl
}

\title{
ZALEŻNOŚCI MIEDZY POZIOMEM WITAMINY D A ILOŚCIA TKANKI TŁUSZCZOWEJ CZŁOWIEKA
}

\section{WSTEP}

Witamina $\mathrm{D}_{3}$ (wit. D) znana jako cholekalcyferol, odgrywa kluczowa rolę w utrzymaniu homeostazy wapniowo-fosforanowej organizmu, wpływajacc na prawidłowe procesy mineralizacji tkanki kostnej (SASSI i współaut. 2018). W związku z odkryciem receptora dla wit. D (VDR) i enzymu 1-a-hydroksylazy, których ekspresję poza układem kostnym obserwuje się np. w komórkach jelita czy płytkach krwi (D'AMELIO i współaut. 2012), w dotychczasowych badaniach podkreśla się plejotropowe działanie wit. D. Może mieć to swoje odzwierciedlenie w potencjalnym wpływie tej witaminy na układ immunologiczny, mięśniowy i krwionośny (WILSON i współaut. 2017). Nieprawidłowa dieta i unikanie bezpośredniej ekspozycji na światło słoneczne spowodowane trybem życia lub pora roku, może być powodem powstawania niedoborów wit. D w organizmie. Niedobory te zwiazane sa przede wszystkim ze wzrostem ryzyka wystapienia schorzeń układu kostnego, tj. rozwoju osteoporozy u dorosłych, natomiast znaczna część przeprowadzonych dotychczas badań, odnosi się głównie do powiazań między poziomem wit. D w organizmie a powstawaniem zaburzeń metabolicznych prowadzacych do powstania cukrzycy typu I, chorób nowotworowych i autoimmunologicznych (KURYŁOWICZ i współaut. 2007, KUPISZ-URBAŃSKA i GALUS 2011).
Najnowsze doniesienia sugeruja, że wahania poziomu wit. D, moga wywoływać zmiany w składzie ciała u ludzi, prowadzac np. do zwiększania masy tkanki tłuszczowej (KRASIŃSKA i SKOWROŃSKA 2014, WALSH i współaut. 2017).

\section{SYNTEZA WITAMINY D}

Podstawowe działanie wit. D opiera się na występowaniu jej dwóch form chemicznych: $\mathrm{D}_{2}$, tzw. ergokalcyferolu, oraz $\mathrm{D}_{3}$ czyli cholekalcyferolu. Forma $\mathrm{D}_{3}$ cechuje się wyższa aktywnościa biologiczna od formy $\mathrm{D}_{2}$ (PRENTICE i współaut. 2008). Witamina $\mathrm{D}$ jest zwiąkiem dobrze rozpuszczalnym w tłuszczach, a jej źródłem w codziennej diecie moga być tłuste ryby, jaja i nabiał. Ze względu na jej ograniczone występowanie w żywności, ludzki organizm ewolucyjnie wykształcił proces jej wytwarzania na drodze dwuetapowej syntezy skórnej (WALICKA i współaut. 2019).

Proces syntezy wit. D zachodzi podczas bezpośredniego naświetlania skóry promieniami słonecznymi, w których skład wchodzi m.in. promieniowanie UVB o długości fali 290-315 nm (WILsON i współaut. 2017). W keratynocytach pod wpływem promieniowania UVB pochodna cholesterolu o właściwościach prowitaminy $\mathrm{D}_{3}$ (7-dehydrocholesterol) przekształcana jest do prewitaminy D, która 
po termicznej izomeryzacji podlega przemianie we właściwa formę witaminy D - cholekalcyferol (PŁUDOWSKI i współaut. 2018). W przypadku przyjmowania wit. D dostarczanej wraz $z$ pokarmem lub $w$ formie suplementów diety, jest ona wchłaniania $z$ jelita cienkiego i za pomoca chylomikronów przedostaje się do układu limfatycznego, ską transportowana jest do żyły głównej i trafia do wątroby (JONES 2012, JONES i współaut. 2012, 2014).

Witamina D powstała na drodze syntezy skórnej lub dostarczana $z$ żywnością nie wykazuje aktywności biologicznej. Za pomoca białek wiażacych witaminę D (ang. binding vitamin D protein, DBP), jej nieaktywna forma transportowana jest do watroby, gdzie za pośrednictwem 25-hydroksylazy $\mathrm{D}_{3}$ (CYP2R1) ulega hydroksylacji i przekształceniu w formę 25-hydroksywitaminy D $\left(25(\mathrm{OH}) \mathrm{D}_{3}\right)$. Forma $25(\mathrm{OH}) \mathrm{D}_{3}$ krążąc po ustroju odzwierciedla stężenie w osoczu i jest swoistym biomarkerem poziomu witaminy $\mathrm{D}$, wykorzystywanym podczas oznaczania jej poziomu. Poczatkowo, powstała w wattrobie forma $25(\mathrm{OH}) \mathrm{D}_{3}$ (kalcyfediol) ulega wiazaniu $z$ DBP i wykrywalna jest $\mathrm{w}$ surowicy. W następnym etapie, forma $25(\mathrm{OH}) \mathrm{D}_{3}$ zwiazana $z$ DBP trafia do nerek, gdzie przy pomocy enzymu 1-a-hydroksylazy 25-hydroksywitaminy D (CYP27B1) ulega hydroksylacji do aktywnej postaci hormonalnej $1,25(\mathrm{OH})_{2} \mathrm{D}_{3}$, zwanej kalcytriolem (KRASIŃSKA i SKOWRONSSKA 2014, MARCINKOWSKA i wspó1aut. 2019). Poza komórkami nerek, ekspresję genu CYP27B1 kodującego 1-a-hydroksylazę obserwuje się również w komórkach płuc, tkance kostnej, wattrobie, łożysku, a także w skórze (GALANT i współaut. 2016). Obecność kalcytriolu została potwierdzono również w komórkach $\beta$ wysp trzustkowych, mięśniach gładkich i w śródbłonku naczyń krwionos̉nych (ŻUKOWSKA-SZCZECHOWSKA i KISZKA 2011).

W nerkach, poza przemiana wit. D do formy $1,25(\mathrm{OH})_{2} \mathrm{D}_{3}$ przy udziale CYP27B1, dochodzi również do jej przemiany w formę $24,25(\mathrm{OH})_{2} \mathrm{D}_{3}$ za pomoca jednego $\mathrm{z}$ mitochondrialnych enzymów cytochromu P450 błony wewnętrznej (CYP24A1). Enzym ten, poza hydroksylacją formy $25(\mathrm{OH}) \mathrm{D}_{3}$, może również hydroksylować formę $1,25(\mathrm{OH})_{2} \mathrm{D}_{3}$, a jego obecność obserwuje się we wszystkich komórkach $z$ obecnym receptorem VDR. CYP241A wpływa także na modulację poziomu krażącego $1,25(\mathrm{OH})_{2} \mathrm{D}_{3} \mathrm{w}$ tkankach docelowych dla wit. D (np. w tkance kostnej), co zapewnia jego prawidłowa odpowiedź po przyłaczeniu się do receptora VDR oraz kontroluje jego ilość w organizmie na drodze ujemnego sprzężenia zwrotnego (SHINKI i współaut. 1992, OHYAMA i współaut. 1993, JONES 2012, JONES i współaut. 2012).
W tkankach $1,25(\mathrm{OH})_{2} \mathrm{D}_{3}$ ulega odłaczeniu od DBP i wiąże się $z$ wewnatrzkomórkowym receptorem VDR. Następnie powstały kompleks kalcytriol-receptor VDR wiąże się $Z$ receptorami retinowymi $\mathrm{RXR}$, tworzac heterodimer. Nowopowstały kompleks heterodimeru pozwala na wiazanie czynników i koaktywatorów transkrypcyjnych (np. koaktywatora receptora jadrowego 1) ze specyficznymi sekwencjami DNA, co wpływa na regulujacę metabolizmu poszczególnych komórek. W konsekwencji, może dochodzić do regulacji procesów transkrypcyjnych, obejmującej aktywację ponad 900 genów. Może mieć to swoje odzwierciedlenie np. w procesie kierunkowania odpowiedzi odpornościowej organizmu. W badaniach wykazano, że wit. D jest w stanie wpływać hamujacco na procesy odporności nabytej, przy jednoczesnym promowaniu mechanizmów odporności wrodzonej. Jednym z przykładów takich właściwości jest zdolność wit. D do indukcji katelicydyny, peptydu o charakterze bakteriobójczym, który obecny jest w komórkach nabłonka. Zaobserwowano również wpływ wit. D na prawidłowe różnicowanie komórek organizmu, np. keratynocytów, a także zdolność do indukcji szlaków apoptozy w różnych komórkach zmienionych nowotworowo (JONES i współaut. 2012, 2014; CHRISTAKos i współaut. 2016). W przypadku jej aktywności metabolicznej udowodniono, iż $1,25(\mathrm{OH}) \mathrm{D}_{2}$ jest $\mathrm{w}$ stanie wspomagać $\mathrm{np}$. wydzielanie insuliny przez komórki $\beta$-trzustki ze względu na obecność w nich receptora VDR (BIKLE 2014).

Efektywność syntezy wit. D droga skórna zależy głównie od stopnia pigmentacji skóry i wieku danej osoby. Dla ludności Europy Środkowej, 15-minutowa ekspozycja na promieniowanie słoneczne 2-3 razy w tygodniu, $z$ odkryciem przedramion i kończyn dolnych, jest optymalnym warunkiem do syntezy wystarczającej ilości wit. D. Najlepsze efekty syntezy skórnej uzyskuje się w słoneczne dni, pomiędzy godzina 10 a 15, przy braku stosowania kremów $z$ filtrem, chroniących skórę przed promieniowaniem UV (PŁUDOWSKI i współaut. 2013).

\section{RECEPTOR VDR}

Receptor VDR zbudowany jest z 427 aminokwasów i składa się $z$ trzech głównych domen. Pierwsza, to N-końcowa domena wiażąca DNA (DBD), posiadajaca dwa palce cynkowe, które wiaża się $z$ odpowiednimi rowkami DNA reagujacymi na przyłaczanie wit. D. Druga, to C-końcowa domena wiażaca się $z$ ligandem (LBD), trzecia zaś stanowi elastyczny region zawiasowy, który łączy DBD z LBD (HAUSSler i współaut. 2011, BiKLe 2014). 
Obecność receptora dla wit. D pośredniczy w działaniu biologiczne aktywnej formy $1,25(\mathrm{OH})_{2} \mathrm{D}_{3} \mathrm{i}$ występuje $\mathrm{w}$ większości komórek organizmu, m.in. w komórkach nerek, układu odpornościowego czy nawet w adipocytach. Występowanie VDR w tak różnorodnej grupie komórek warunkuje wielokierunkowy mechanizm działania wit. D. Najsilniejsza ekspresję VDR obserwuje się w tkance kostnej, komórkach nerek i jelit, a także w gruczołach przytarczycznych, co jest bezpośrednio związane $z$ utrzymywaniem homostazy wapniowo-fosforanowej organizmu (WANG i współaut. 2012, MAESTRO i współaut. 2016). VDR należy do grupy receptorów steroidowych, podobnie jak receptory hormonow płciowych, kwasu retinowego i steroidów kory nadnerczy (MARGOLIS i CHRistakos 2010).

Działanie receptora VDR w jądrze komórkowym jest ściśle zwiazane $z$ regulacja ekspresji genów, których produkty wpływaja na funkcje biologiczne danej komórki i reguluja homeostazę mineralną organizmu (PIKE i współaut. 2017). Aktywacja receptora VDR wiąze się $z$ ich wpływem na regulację procesów wzrostu komórkowego, proliferację, regulację procesów apoptozy i aktywację komórek immunokompetentnych (PEELEN i współaut. 2011).

Ekspresja receptorów VDR w adipocytach jest zwiazana $z$ procesami regulujacymi metabolizm energetyczny komórek oraz może być zwiazana $z$ występowaniem otyłości u ludzi (WYSOCZAŃSKA-KLACZYŃSKA i współaut. 2018)

U myszy, u których wprowadzono ludzki gen $h V R D$ obserwowano otyłość, natomiast myszy pozbawione genu VRD wykazywały spadek masy ciała, przy zachowaniu identycznego sposobu ich odżywiania, co potwierdziło rolę tego receptora w zwiększeniu masy tkanki tłuszczowej (PELCZYŃSKA i współaut. 2017).

\section{WZAJEMNA KORELACJA MIEDZY TKANKA TŁUSZCZOWA A WIT. D}

Tkanka tłuszczowa powstaje na drodze adipogenezy. Pod wpływem czynników wzrostowych i hormonow mezynchemalne komórki macierzyste przekształcają się w pre-adipocyty, a następnie różnicują w adipocyty, które, ulegajac zmianom biochemicznym i morfologicznym, osiagają dojrzałość funkcjonalną. Rola dojrzałych adipocytów jest synteza trójglicerydów, odpowiadanie na insulinę i produkcja adipokin (WOOD 2008).

Tkanka tłuszczowa w organizmie człowieka uważana jest za główny magazyn witaminy D. W adipocytach, dzięki obecności VDR, wit. D jest w stanie wpływać na regulację ekspresji genów w tych komórkach i regulo- wać procesy apoptozy. Witamina D wpływa także na regulacje ekspresji genów związanych $z$ adipogeneza, procesami zapalnymi, stresem oksydacyjnym i metabolizmem dojrzałych adpicotów (RUIZ-OJEDA i współaut. 2018). Uczestniczy ona również w regulacji metabolizmu energetycznego poprzez kontrolowanie ekspresji termogeniny, czyli białka obecnego w wewnętrznej błonie mitochondriów w brunatnej tkance tłuszczowej. Termogenina stanowi marker brunatnej tkanki tłuszczowej i, biorac udział w termogenezie bezdrżeniowej, odpowiada za powstawanie energii w postaci ciepła (ABBAS 2017; STOSIO i współaut. 2016).

\section{WPEYW STEŻENIA WITAMINY D NA MASE TKANKI TŁUSZCZOWEJ}

Szacuje się, że niedobory wit. D notuje się nawet u 1 miliarda osób na świecie, z czego np. w Stanach Zjednoczonych największe jej niedobory notowane sa u dzieci w wieku 6-18 lat $z$ nadwaga i ze zdiagnozowana otyłościa znacznego stopnia. Korelacja między niskimi stężeniami wit. D a występowaniem otyłości u ludzi została potwierdzona wieloma badaniami, natomiast nie do końca znane sa mechanizmy tego zjawiska (KRASIŃSKA i SKOWROŃSKA 2014).

Według najnowszych ustaleń Światowej Organizacji Zdrowia, do końca 2020 r. liczba dzieci $z$ nadwaga i otyłych wzrośnie do 9,1\%. Podwyższony wskaźnik BMI (ang. body mass index) w wieku dziecięcym może skutkować rozwojem cukrzycy typu II i chorób układu krażenia w życiu dorosłym (PARK i współaut. 2012, MAJORCZYK i współaut. 2016).

U dorosłych wystapienie nadwagi definiowane jest wartością wskaźnika BMI powyżej $25 \mathrm{~kg} / \mathrm{m}^{2}$, w przypadku otyłości wskaźnik BMI musi być większy bądź równy $30 \mathrm{~kg} /$ $\mathrm{m}^{2}$. Szacuje się, że przy obecnym trendzie występowania otyłości, do 2030 r. u 38\% populacji światowej zostanie stwierdzona nadwaga, natomiast u 20\% zdiagnozuje się otyłość (SMith i SMiTh 2016).

Poza czynnikami środowiskowymi, złym sposobem żywienia oraz brakiem aktywności fizycznej i występowaniem chorób współistniejących, otyłość może być determinowana czynnikami genetycznymi. Geny, których warianty moga sprzyjać rozwojowi otyłości to m.in.: LEP, FTO (ang. fat mass and obesity associated gene), TMEM18, GNPDA2 i VDR (LOOS i BOUCHARD 2008, MAJORCZYK i współaut. 2016).

Dane literaturowe mówiące o związku między występowaniem otyłości a wit. D sugerują, że istnieja dwa procesy odpowiedzialne za występowanie tej zależności. Pierwszy dotyczy mechanizmów związanych $z$ wpły- 
wem wit. D na ekspresję genów w komórkach, drugi - przekazywania sygnałów w komórce, bez wywierania wyplywu na ekspresję genów (MAJORCZYK i współaut. 2016). Większość publikowanych wyników badań podkreśla jednak rolę genów odpowiedzialnych np. za szlak metaboliczny wit. D, samo jej działanie, a także genów kodujacych min.: DBP (DBP/CG), VDR, 25-hydroksylaze (CYP2R1), reduktaze 7-dehydrocholesterolu (DHCR7), receptor RXR (RXR), receptory wapniowe (CASR) oraz innych genów: CYP27B1, CYP24A1, NPY, FOXA2, SSTR4, IVL (RuIz-OJEDA i współaut. 2018). Wymienione geny wpływaja min. na etapy poprzedzajace syntezę samego $25(\mathrm{OH}) \mathrm{D}_{3}$, aktywację wit. D, produkcję i sprzęganie $25(\mathrm{OH}) \mathrm{D}_{3} \mathrm{z}$ VDB oraz syntezę receptorów i białek koaktywujacych wiazanie wit. D z VDR (JoLLIFFE i współaut. 2016, RUIZ-OJEDA i współaut. 2018).

\section{PRAWIDŁOWE STEŻENIE WITAMINY D W ORGANIZMIE}

Podczas oznaczeń stężenia wit. D przyjęto, iż wartość $25(\mathrm{OH}) \mathrm{D}_{3} \mathrm{w}$ surowicy $\mathrm{w}$ granicach od 75 do $125 \mathrm{nmol} / \mathrm{L}(30-50 \mathrm{ng} / \mathrm{mL})$ jest stężeniem optymalnym, a profilaktyczna suplementacja ustalana przez lekarza musi być dostosowana do wieku pacjenta, pory roku, trybu życia i wspólistnienia chorób. Wartości poniżej $75 \mathrm{nmol} / \mathrm{L}(\leq 30 \mathrm{ng} / \mathrm{mL})$ klasyfikowane sa jako stężenie suboptymalne $i$ wymagaja zwiększenia suplementacji wit. D o 50\% wartości dawki poprzedniej lub jej wprowadzenia w przypadku braku wcześniejszego stosowania. Wartości poniżej $50 \mathrm{nmol} / \mathrm{L}$ ( $\leq 20 \mathrm{ng} / \mathrm{mL}$ ) uważane sa za stężenia świadczace o znacznym niedoborze i wymagaja zwiększenia obecnej suplementacji o $100 \%$ dawki poprzedniej. Oznaczane stężenia poniżej $25 \mathrm{nmol} / \mathrm{L}(\leq 10 \mathrm{ng} /$ $\mathrm{mL})$ świadcza o ciężkich niedoborach prowadzacych do powstawania deformacji kości, krzywicy u dzieci i osteomalacji u osób dorosłych (RUSIŃSKA i współaut. 2018). W rekomendacjach dla Europy Środkowej dotyczących profilaktyki niedoborów wit. D, dla osób dorosłych zaleca się przyjmowanie cholekalcyferolu w ilości 800-2000 j.m. dziennie (jednostki międzynarodowe; ang. international unit, IU), odpowiadające ilości 20-50 $\mu \mathrm{g}$ cholekalcyferolu. Dla osób otyłych dawka suplementacji powinna być zwiększona odpowiednio od 1600 do 4000 j.m., zależnie od stopnia otyłości. W przypadku leczenia ciężkich niedoborów wit. D zaleca się stosowanie dawki od 2000-6000 j.m. na dobę, w zależności od wieku (PeUdowSKI i współaut. 2018, RUSIŃSKA i współaut. 2018).

\section{ZWIEKSZONA MASA CIAEA I \\ NIEDOBORY WIT. D - HIPOTEZY ZWIAZZANE $Z$ NIEDOBOREM WIT. U OSÓB Z OTYŁOŚCIA}

Jak już wspomniano, u pacjentów, u których poziom wit. D w surowicy wykazuje wyraźne niedobory lub wartości poniżej normy, coraz częściej obserwuje się występowanie chorób metabolicznych i otyłości, czego mechanizm nadal nie jest znany. Jednym $z$ wyjaśnień może być hipoteza sekwestracji, czyli odkładania wit. D w tkance tłuszczowej, lub negatywnego oddziaływania na układ dokrewny wywieranego przez zwiększona ilość krażącego $1,25(\mathrm{OH})_{2} \mathrm{D}_{3}$ (PouRsHAHIDI 2015). Według SAVASTANO i współaut. (2017), problemowi otyłości i niedoborom wit. D nadano range epidemii o zasięgu światowym. Przy założeniu, że osoby otyłe prowadza bardziej siedzacy tryb życia i wykazuja mniejsza aktywność na świeżym powietrzu, może skutkować to występowaniem obniżonej wydajności syntezy skórnej wit. D w ich organizmie (MARKS 2020).

W badaniach po raz kolejny zwraca się szczególną uwage na fakt sekwestracji wit. D w tkance tłuszczowej. Co więcej, niektóre badania wskazujace obniżony poziom wit. D sugeruja, że jest ona rozpuszczana w nadmiarze tkanki tłuszczowej u osób otyłych (CARRELLI i współaut. 2017). Wykazano również, że tkanka ta pełni role swoistego regulatora zapobiegajacego nadmiernemu $i$ niekontrolowanemu powstawaniu $25(\mathrm{OH})$ $\mathrm{D}_{3} \mathrm{w}$ watrobie. Dodatkowo $\mathrm{u}$ osób $\mathrm{Z}$ nadmierną masa ciała, odnotowuje się wzmożoną syntezę aktywnego metabolitu wit D. $(1,25(\mathrm{OH}) 2 \mathrm{D}) \mathrm{w}$ nerkach, który w mechanizmie ujemnego sprzężenia zwrotnego może hamować produkcję $25(\mathrm{OH}) \mathrm{D}_{3} \mathrm{w}$ wątrobie. Wobec czego można wnioskować, że nadmiar tkanki tłuszczowej w organizmie może wpływać negatywnie na poziom wit. D (ŁUPIŃSKA i CHLEBNA-SOKÓ£ 2016, SAVASTANO i współaut. 2017, MARKS 2020).

Istnieje również założenie dotyczace zmniejszonej ekspresji enzymów aktywujacych wit. D, tj. 1a-hydroksylazy i 25-hydroksylazy w komórkach tkanki tłuszczowej u osób otyłych, w porównaniu do prawidłowej masy ciała, co może wpływać na ilość dostepnej wit. D w organizmie (WAMBERG i współaut. 2013).

Badania zespołu ŁUPIŃsKIEJ i CHLEBNEJ-SoKó£ (2016) przeprowadzone na grupie 80 dzieci wykazały, iż niedobory wit. D częściej występowały u pacjentów $z$ otyłościa $i$ nadwaga niż w przypadku pacjentów o prawidłowej masie ciała. Obserwowano ujemna korelację między masa ciała, masa tkanki tłuszczowej a stężeniem wit. D w surowicy. W każdej $z$ badanych grup występował nie- 
dobór wit. D, co wymaga podjęcia działań w postaci jej suplementacji oraz popularyzacji informacji o roli wit. D w organizmie człowieka. Obserwuje się istotna statystycznie zależność pomiędzy ilością tkanki tłuszczowej, masa ciała a stężeniem $25(\mathrm{OH}) \mathrm{D}_{3}$, co dodatkowo potwierdza, że otyłość może być spowodowana m.in. niedoborami wit. D (ŁUPIŃSKA i CHLEBNA-SOKÓE 2016). Metaanaliza przeprowadzona w 2015 r. przez PEREIRA-SANTOS i współaut. wykazała, iż występowanie niedoborów wit. D u osób otyłych i z nadwaga było wyższe odpowiednio o 35\% i $24 \%$ w porównaniu $z$ osobami bez niedoborów, bez względu na grupę wiekową.

\section{WITAMINA D JAKO CZYNNIK ZMNIEJSZAJACY ILOSC TKANKI TŁUSZCZOWEJ}

$\mathrm{W}$ badaniach in vitro udowodniono, że $1,25(\mathrm{OH})_{2} \mathrm{D}_{3}$ może wpływać na masę tkanki tłuszczowej poprzez hamowanie adipogennych czynników transkrypcyjnych (tj. C/ EBP $\beta$ odpowiedzialnego za wiazanie się $z$ sekwencja regulatorowa CCATT; PPARy, czynnika dla receptorów aktywowanych przez proliferatory peroksysomów, oraz SREBP 1, czyli białka wiążącego element regulatorowy steroli 1) i zatrzymywanie akumulacji lipidów w adipocytach. Dodatkowo $1,25(\mathrm{OH})_{2} \mathrm{D}_{3}$ powoduje zwiększenie poziomu mRNA genu Insig-2, który odpowiada za blokowanie syntezy kwasów tłuszczowych w dojrzałych adipocytach oraz hamuje różnicowanie preadipocytów do adipocytów, zapobiegajac powstawaniu nadmiernej ilości tkanki tłuszczowej (DING i współaut. 2012)

Badania na modelach szczurzych dowiodły, że u osobników $z$ niedoborami wit. D obserwowano mniejszą masę ciała i ilość tłuszczu, co stanowi odwrotność wcześniej stawianej hipotezy, świadczącej o zwiększonej objętości tkanki tłuszczowej powiazanej $z$ obniżonym poziomem wit. D u ludzi. Ponadto, odnotowano niski poziom leptyny, który jednocześnie odzwierciedla ilość tkanki tłuszczowej w organizmie. Zauważono także, że osobniki $z$ niedoborami wit. D cechowały się mniejszą ekspresją genów odpowiedzialnych za adipogenezę, w porównaniu $z$ próba kontrolna - szczury $z$ prawidłowym poziomem wit. D (BHAT i współaut. 2014).

PRUSZKOWSKA-PRZYBYLSKA i współaut. (2020) przeprowadzili badania stężenia $25(\mathrm{OH}) \mathrm{D}_{3} \mathrm{w}$ ślinie oraz składu ciała wśród 182 dzieci w wieku 6-13 lat, uczęszczajacych do szkół podstawowych w Polsce centralnej, w których nie wykazano istotnego zwiąku między stężeniem wit. D a składem ciała. W publikowanych wynikach obserwuje się pewne rozbieżności, gdyż np. w meta- analizie przeprowadzonej przez PERNA (2019) zaobserwowano, iż po suplementacji wit. D w grupie 947 osób borykających się $z$ otyłością lub nadwaga, cholekalcyferol średnio statystycznie obniża współczynnik BMI o $0,32 \mathrm{~kg} / \mathrm{m}^{2}$, ale nie wpływa statystycznie na utrate masy ciała. W innych badaniach na grupie 439 kobiet w okresie postmenopauzalnym ze stwierdzoną otyłościa lub $z$ nadwaga oceniano wpływ 12-miesięcznej suplementacji wit. D na utrate masy ciała. Kobiety podzielono na cztery grupy: zmiana diety, zwiększenie aktywności fizycznej, połącenie diety $z$ aktywnością fizyczna i grupa kontrolna. Nie zaobserwowano istotnych zmian $\mathrm{w}$ poziomie $25(\mathrm{OH}) \mathrm{D}_{3}$ w surowicy między kobietami $z$ grup, w których wprowadzono działania majace na celu utrate masy ciała a grupa kontrolna. Co ciekawe, notowano wzrost średniej ilości $25(\mathrm{OH}) \mathrm{D}_{3}$ w surowicy u kobiet, które utraciły większy procent masy ciała względem masy wyjściowej. Wykazano, że stopień utraty wagi u kobiet stosujących niskokaloryczną dietę lub częstsza aktywność fizyczna, wiąże się ze zwiększonym stężeniem 25(OH)D w surowicy (MASON i współaut. 2011). Dodatkowo, BRZEZIŃSKI i współaut. (2020) w programie kontroli wagi, przeanalizowali wpływ suplementacji wit. D pod katem utraty masy ciała dzieci $z$ nadwaga lub otyłościa. Przez 26 tygodni u 152 pacjentów w wieku 6-14 lat $z$ niedoborami wit. D stosowano jej suplementacje w ilości 1200 IU lub podawano placebo. Badania finalnie zakończyło 109 pacjentów, u których, w porównaniu $z$ grupa przyjmująca placebo, nie zaobserwowano istotnych statystycznie zmian w poziomie BMI i w poziomie redukcji masy tłuszczowej.

\section{POLIMORFIZM VDR A OTYŁOŚĆ}

Gen VDR obecny na długim ramieniu 12 chromosomu posiada wiele polimorfizmów odpowiedzialnych za rozwój licznych chorób metabolicznych, w tym otyłości. Do tej pory nie do końca wyjaśniono zależności między konkretnymi polimorfizmami tego genu a występowaniem otyłości.

W metaanalizie przeprowadzonej przez CHEN i współaut. (2019) oceniano podatność na wystapienie otyłości powiazanej ze zmiennościami genetycznymi w receptorze VDR. Analizowano 4 polimorfizmy VDR: ApaI, BsmI, FokI i TaqI, na próbie 1188 osób otyłych i 1657 zdrowych. Wyniki wskazały na brak powiązań między ryzykiem wystapienia otyłości a polimorfizmem VDR w locus ApaI, BsmI i TaqI. Jednak u Azjatów homozygot, heterozygot $\mathrm{i}$ heterozygot dominujących odnotowano powiazanie między polimorfizmem TaqI a wystąpieniem otyłości. W przypadku 
polimorfizmu FokI w receptorze VDR, odnotowano zwiększone ryzyko wystapienia otyłości tylko w przypadku heterozygot dominujacych.

Badania młodych dorosłych pochodzenia Kaukaskiego wykazały, że polimorfizmy TaqI, $B s m l$, Fokl w receptorze VDR nie odgrywały kluczowej roli $\mathrm{w}$ powstawaniu otyłości (CORREA-RODRÍGUEZ i współaut. 2018). Istnieje wiele doniesień świadczących o powiązaniach genetycznych między genami kodujacymi 25-hydroksywitaminę D, w szczególności polimorficznych genów receptora VDR, a samymi cechami otyłości. Uważa się także, że gen $D B P / G C$ kodujacy DBP może odgrywać kluczowa rolę $\mathrm{w}$ występowaniu otyłości a poziomem wit. D (RUIZ-OJEDA i współaut. 2018).

\section{PODSUMOWANIE}

Dzięki plejotropowemu działaniu witaminy $\mathrm{D}$, jest ona niezbędnym składnikiem zapewniajacym prawidłowe funkcjonowanie organizmu, stąd tak ważne jest monitorowanie jej poziomu i usuwanie powstających niedoborów. Dostępne dane literaturowe dotyczace oddziaływania pomiędzy zmianami poziomu $25(\mathrm{OH}) \mathrm{D}_{3}$ a masa ciała wciąż niejednoznacznie wskazuja na przyczyny powstawania tego zjawiska. W większości przeprowadzonych badań obserwuje się trend występowania zwiększonej masy ciała $u$ osób $z$ obniżonym poziomem wit. D. Uważa się, że może być to spowodowane występowaniem m.in. polimorfizmu VDR (CHEN i współaut. 2019), genów odpowiedzialnych za szlak metaboliczny $25(\mathrm{OH}) \mathrm{D}_{3}$, genów kodujacych DBP, 25-hydroksylazę, receptory VDR czy 7-dehydrocholesterolu, co może wpływać na stężenie dostępnego $25(\mathrm{OH}) \mathrm{D}_{3} \mathrm{w}$ surowicy (RUIZ-OJEDA i współaut. 2018). W większości publikacji powtarzają się hipotezy sekwestracji wit. D w tkance tłuszczowej (EUPIŃSKA i CHLEBNA-SOKÓє 2016), występowanie zwiększonego poziomu $1,25(\mathrm{OH}) 2 \mathrm{D}$ w nerkach osób otyłych hamujacego produkcję $25(\mathrm{OH}) \mathrm{D}_{3} \mathrm{w}$ watrobie na drodze ujemnego sprzężenia zwrotnego (SAVASTANO i współaut. 2017) czy też obniżona aktywność enzymów aktywujacych wit. D w samej tkance tłuszczowej, zmniejszających stężenie wit. D. Ponadto, u osób otyłych niedobry wit. D wynikaja często $z$ niewystarczajacej ekspozycji na światło słoneczne, spowodowanej brakiem aktywności fizycznej na świeżym powietrzu, co może wynikać ze względów psychospolecznych zwiazanych $z$ dyskomfortem wygladu fizycznego (MARKS 2020).

$Z$ drugiej strony, coraz więcej doniesień wskazuje na brak istotnego zwiazku pomiędzy obniżonym poziomem wit. D a składem ciała, w tym występowaniem nadmiernej ilości tkanki tłuszczowej (PruszKowsKA-PRZYBYLSKA i współaut. 2020) oraz podkreśla możliwość występowanie wplywu wit. D na obniżanie wskaźnika BMI, ale nie samej tkanki tłuszczowej (Perna 2019). Co więcej, $\mathrm{w}$ badaniach in vitro obserwowano hamujacy efekt $1,25(\mathrm{OH})_{2} \mathrm{D}_{3}$ na adipogenne czynniki transkrypcyjne oraz odnotowano blokujacy wpływ na syntezę kwasów tłuszczowych w adipocytach (DiNG i współaut. 2012). Badania na modelach szczurzych wykazały, iż osobniki z niedoborem wit. D cechowaly się mniejsza masa ciała i ekspresja adipogennych genów.

Niewatpliwie, istnieje konieczność dalszego prowadzenia badań, skupiajacych się głównie na molekularnym podłożu korelacji wpływu stężenia witaminy D w organizmie człowieka na zjawisko zmian w masie ciała, szczególnie w postawaniu otyłości i nadwagi.

$$
\text { Streszczenie }
$$

Witamina $\mathrm{D}_{3}$ poza utrzymaniem homeostazy wapniowo-fosforanowej ma również istotny wpływ m.in. na układ odpornościowy, mięśniowy czy krwionośny. Dzięki występowaniu receptorów dla witaminy $\mathrm{D}$ w wielu komórkach organizmu, obserwuje się jej działanie wielokierunkowe. Nieprawidłowa dieta oraz brak ekspozycji na światło słoneczne, moga prowadzić do powstawania niedoborów wit. D i sprzyjać rozwojowi np. osteoporozy oraz krzywicy u dzieci. Ostatnie badania dowiodły, iż zmiany poziomiu wit. D mogą wpływać m.in. na powstawanie chorób metabolicznych, tj. cukrzycy typu I, prowadząc do rozwoju nadwagi i otyłości. U osób $Z$ obniżonym poziomem wit. D obserwuje się występowanie zwiększonej masy ciała, co może wiąać się $z$ hipoteza tzw. odkładania wit. D w nadmiernej ilości tkanki tłuszczowej. Z drugiej strony istnieja doniesienia świadczace o tym, że wit. D wpływa na zmniejszenie ilości tkanki tłuszczowej. Należy przeprowadzić więcej badań weryfikujacych molekularne podłoża korelacji między stężeniem witaminy D a występowaniem nadwagi i otyłości.

\section{LITERATURA}

AbBas M. A., 2017. Physiological functions of Vitamin $D$ in adipose tissue. J. Steroid Biochem. Mol. Biol. 165, 369-381.

BHAT M., NOOLU B., QADRI S. S., IsMaIl A., 2014. Vitamin $D$ deficiency decreases adiposity in rats and causes altered expression of uncoupling proteins and steroid receptor coactivator. J. Steroid Biochem. Mol. Biol. 144, 304-312.

BIKLE D. D., 2014. Vitamin D metabolism, mechanism of action, and clinical applications. Chem. Biol. 21, 319-329.

BRZEZIŃSKI M., JANKOWSKA A., SŁOMIŃSKA-FrACZEK M., MeTElska P., WiśnieWsKi P., SOCHA P., SZLAGATYS-SIDORKIEWICZ A., 2020. Longterm effects of vitamin $D$ supplementation in obese children during integrated weight-loss programme. A double blind randomized placebo-controlled trial. Nutrients 12, doi: 10.3390/ nu 12041093.

CARREll A., BUCOVSKY M., HORST R., CREMERS S., ZHANG C., Bessler M. i współaut., 2017. Vitamin $D$ storage in adipose tissue of obese 
and normal weight women. J. Bone Mineral Res. 32, 237-242.

Chen X., Wang W., Wang Y., HaN X., GaO L., 2019. Vitamin D Receptor Polymorphisms Associated with Susceptibility to Obesity: A Meta-Analysis. Med. Sci. Monitor, Int. Med. J. Exp. Clin. Res. 25, 8297-8305.

Christakos S., Dhawan P., Verstuyf A., VerlinDEN L., CARMELIET G., 2016. Vitamin D: metabolism, molecular mechanism of action, and pleiotropic effects. Physiol. Rev. 96, 365-408.

CORREA-RODRÍGUEZ M., CARRILlO-Ávila J. A., SCHMIDT-RIOVALLE J., GONZALEZ-JIMENEZ E., VARGAS S., MARTÍN J., RUEDA-MEDINA B., 2018. Genetic association analysis of vitamin $D$ receptor gene polymorphisms and obesity-related phenotypes. Gene 640, 51-56.

D'Amelio P., Cristofaro M. A., De Vivo E., RaVaZzoli M., Grosso E., Di Bella S., Aime M., Cotto N., Silvagno F., Isaia G. C., PescarMONA G. P., 2012. Platelet vitamin D receptor is reduced in osteoporotic patients. Panminerva Med. 54, 225-231.

Ding C., GaO D., Wilding J., TRAYhURN P., Bing C., 2012. Vitamin $D$ signalling in adipose tissue. Brit. J. Nutrit. 108, 1915-1923.

Galant K., BARG E., KazANOWSKA B., 2016. Witamina $D$ a choroby metaboliczne, autoimmunologiczne $i$ nowotworowe. Pediatr. Endocrinol. Diabet. Metab. 24, 32-38.

HAUSSlER M. R., JURUTKA P. W., MizWICKI M., NORMAN A. W., 2011. Vitamin $D$ receptor (VDR)-mediated actions of $1 a, 25(\mathrm{OH}) 2 v i$ tamin D3: genomic and non-genomic mechanisms. Best Pract. Res. Clin. Endocrinol. Metab. 25, 543-559.

JollifFe D. A., Walton R. T., GRiffiths C. J., MARTINEAU A. R., 2016. Single nucleotide polymorphisms in the vitamin D pathway associating with circulating concentrations of vitamin $D$ metabolites and non-skeletal health outcomes: review of genetic association studies. J. Steroid Biochem. Mol. Biol. 164, 18-29.

Jones G., 2012. Metabolism and biomarkers of vitamin $D$. Scand. J. Clin. Lab. Invest. 72 (Suppl. 243), 7-13.

JONES G., PROSSER D. E., KaUfMann M., 2012. 25-Hydroxyvitamin D-24-hydroxylase (CYP24A1): its important role in the degradation of vitamin $D$. Arch. Biochem. Biophys. 523, 9-18.

Jones G., Prosser D. E., Kaufmann M., 2014. Cytochrome P450-mediated metabolism of vitamin D. J. Lipid Res. 55, 13-31.

KRASIŃSKA A., SKOWROŃSKA B., 2014. Znaczenie witaminy $D$ u pacjentów $z$ nadmierna masa ciała - nowe zasady suplementacji. Forum Zaburzeń Metabolicznych 5, 63-70.

KUPISZ-URBAŃSKA M., GaLUS K., 2011. Epidemiologia niedoboru witaminy $D$ u osób $w$ podeszłym wieku - wybrane zagadnienia. Gerontol. Pol. 19, 1-6.

KurYŁowicz A., BEDNARCZUK T., NAUMAN J., 2007. Wpływ niedoboru witaminy $D$ na rozwój nowotworów $i$ chorób autoimmunologicznych. Endokrynol. Pol. 58, 140-152.

LOOS R. J. F., BOUCHARD C., 2008. FTO: the first gene contributing to common forms of human obesity. Obesity Rev. 9, 246-250.

ŁUPIŃSKA A., CHLEBNA-SoKót D., 2016. Czynniki wpływajace na stęzenie witaminy $D w$ surowicy dzieci łódzkich $w$ wieku wczesnoszkolnym $z$ nadmiarem masy ciała. Post. Nauk Med. 10, 709-715.

MAestro M. A., MOlnÁR F., MOURIÑo A., CARLBERG C., 2016. Vitamin D receptor 2016: novel ligands and structural insights. Expert Opin. Therapeut. Patents 26, 1291-1306.

MAJORCZYK M., BARAN M., JAWOREK J., 2016. Rola witaminy $D w$ rozwoju $i$ przebiegu otyłości. Pielęg Pol. 1, 91-97.

Mason C., XiaO L., Imayama I., Duggan C. R., BAIN C., FOSTER-SCHUBERT K. E. i współaut., 2011. Effects of weight loss on serum vitamin $D$ in postmenopausal women. Am. J. Clin. Nutrit. 94, 95-103.

Marcinkowska M., Mickiewicz A., FiJAeKowski M. 2019. Plejotopowe działanie witaminy D. Choroby Serca i Naczyń 16, 45-52.

MARGOLIS R. N., ChristaKOS S., 2010. The nuclear receptor superfamily of steroid hormones and vitamin $D$ gene regulation. An update. Ann. NY Acad. Sci. 1192, 208-214.

MARKS R., 2020. Obesity, COVID-19 and vitamin $D:$ is there an association worth examining. Adv. Obes. Weight Manag. Control 10, 59-63.

OHYAMA Y., Noshiro M., EgGeRTSEN G., GOTOH O., KATO Y., BJOERKHEM I., OKUDA K., 1993. Structural characterization of the gene encoding rat 25-hydroxyvitamin D3 24-hydroxylase. Biochemistry 32, 76-82.

PARK M. H., FALCONER C., Viner R. A., KinRA S., 2012. The impact of childhood obesity on morbidity and mortality in adulthood: a systematic review. Obesity Rev. 13, 985-1000.

Peelen E., Knippenberg S., Muris A. H., ThewisSen M., Smolders J., Tervaert J. W. C. i współaut., 2011. Effects of vitamin $D$ on the peripheral adaptive immune system: a review. Autoimmun. Rev. 10, 733-743.

Pelczyńska M., Grzelak T., Sperling M., CzyżewSKA K., 2017. Witamina $D$ a funkcje adipocytów. Post. Hig. Med. Dosw. 71, 1189-1197.

Pereira $\square$ Santos M., Costa P. R. D. F., Assis A. M. O. D., SAnTOS C. A. D. S. T., SAnTOS D. B. D., 2015. Obesity and vitamin $D$ deficiency: a systematic review and meta $\square$ analysis. Obesity Rev. 16, 341-349.

PERNA S., 2019. Is vitamin $D$ supplementation useful for weight loss programs? A systematic review and meta-analysis of randomized controlled trials. Medicina 55, doi: 10.3390/medicina55070368.

Pike J. W., Meyer M. B., Lee S. M., Onal M., BENKUSKY N. A., 2017. The vitamin $D$ receptor: contemporary genomic approaches reveal new basic and translational insights. J. Clin. Invest. 127, 1146-1154.

Peudowski P., KarczMarewicz E., Bayer M., CARTER G., Chlebna-SoKÓE D., CZECH-Kowalska J., i współaut., 2013. Practical guidelines for the supplementation of vitamin $D$ and the treatment of deficits in Central Europe - recommended vitamin $D$ intakes in the general population and groups at risk of vitamin $D$ deficiency. Endokrynol. Pol. 64, 319-327.

PŁUdOWSKI P., HOLICK M. F., GRANT W. B., KonSTANTYNOWICZ J., MASCARENHAS M. R., HaQ A. i współaut., 2018. Vitamin $D$ supplementation guidelines. J. Steroid Biochem. Mol. Biol. $175,125-135$

POURSHAHIDI L. K., 2015. Vitamin $D$ and obesity: current perspectives and future directions. Proc. Nutrit. Soc. 74, 115-124.

PREntice A., Goldberg G. R., Schoenmakers I., 2008. Vitamin $D$ across the lifecycle: physiology and biomarkers. Am. J. Clin. Nutriti. 88, 500S-506S.

PRUSZKOWSKA-PRZYBYlSKa P., Sitek A., Rosset I., SOBALSKA-KWAPIS M., SEOMKA M., STRAPAGIEL D. i współaut., 2020. Association of saliva 25 (OH) D concentration with body composition 
and proportion among pre-pubertal and pubertal Polish children. Am. J. Human Biol. 32, doi: $10.1002 /$ ajhb.23397.

Ruiz-OJEDA F. J., ANGUiTA-RUiZ A., LEIS R., AGUILERA C. M., 2018. Genetic factors and molecular mechanisms of vitamin $D$ and obesity relationship. Ann. Nutrit. Metab. 73, 89-99.

RusińSKA A., PludowsKi P., WALCZAK M., BORSZEWSKA-KORNACKA M., BOSSOWSKI A., CHLEBNA-SOKOL D., CZECH-KOWALSKA J., DOBRZAŃSKA A., FRANEK E., HELWICH E., JACKOWSKA T., KALINA M. i współaut., 2018. Zasady suplementacji $i$ leczenia witamina $D$ - nowelizacja 2018 r. http://mavipuro.pl/zasady-suplementacji-i-leczenia-witamina-d-nowelizacja-2018-r/.

SASSi F., TAMONE C., D'AMElio P., 2018. Vitamin $D$ : nutrient, hormone, and immunomodulator. Nutrients 10, doi: 10.3390/nu10111656.

SAVASTANO S., BARREA L., SAVANElli M. C., NAPPI F., Di SOMma C., ORIO F., COlaO A., 2017. Low vitamin $D$ status and obesity: Role of nutritionist. Rev. Endocrine Metab. Disord. 18, 215-225.

SHINKI T., JiN C. H., NishimURA A., NAGAI Y., OHYAMA Y., NOSHIRO M., OKUDA K., SUDA T., 1992 Parathyroid hormone inhibits 25-hydroxyvitamin D3-24-hydroxylase mRNA expres sion stimulated by 1 alpha,25-dihydroxyvitamin D3 in rat kidney but not in intestine. J. Bio.1 Chem. 267, 13757-13762.

Smith K. B., Sмiтh M. S., 2016. Obesity statistics. Prim. Care 43, 121-135.

Stosio M., WitKowicz A., KowAlsKa A., KARABON L., 2016. Genetyczne uwarunkowania zaburzonej ekspresji termogeniny (UCP1) $w$ otyłości prowadzacej do zespołu metabolicznego. Post. Hig. Med. Dosw. 70, 1389-1403.

WALICKA M., JASIK A., PACZYŃSKA M., WAূSOWSKI M., TAEAEAJ M., MARCINOWSKA-SUCHOWIERSKA E., 2019. Niedobór witaminy D - problem społeczny. Post. Nauk Med. 32, 14-22.

Walsh J. S., Bowles S., Evans A. L., 2017. Vitamin $D$ in obesity. Curr. Opin. Endocrinol. Diabet. Obesity 24, 389-394.

Wamberg L., Christiansen T., Paulsen S. K., FISKER S., RASK P., REJNMARK L. i wspólaut., 2013. Expression of vitamin D-metabolizing enzymes in human adipose tissue - the effect of obesity and diet-induced weight loss. Int. J. Obesity 37, 651-657.

WANG Y., ZHU J., DelucA H. F., 2012. Where is the vitamin $d$ receptor? Arch. Biochem. Biophys. 523, 123-133

WILSON L. R., TRIPKOVIC L., HART K. H., LANHAM-NEW S. A., 2017. Vitamin $D$ deficiency as a public health issue: using vitamin $D 2$ or vitamin $D 3$ in future fortification strategies. Proc. Nutrit. Soc. 76, 392-399.

WooD R. J., 2008. Vitamin $D$ and adipogenesis: new molecular insights. Nutrit. Rev. 66, 4046.

WysoczańSKa-KLACZYŃSKa A., ŚlezaK A., HeTMAN M., BARG E., 2018. Wpływ polimorfizmów genu VDR na otyłość, zmiany metaboliczne, zaburzenia masy kostnej $i$ procesy nowotworowe. Pediatr. Endocrinol. Diabetes Metab. 24, 96-105

ŻukowsKA-SzcZechowska E., KIsZKA B., 2011. Niedobór witaminy $D$ - rozpoznawanie $i$ postępowanie $w$ celu redukcji ryzyka sercowo-naczyniowego u chorych na cukrzyce. Forum Zaburzeń Metabolicznych 2, 151-157.

KOSMOS Vo1. 70, 1, 95-102, 2021

JAKUb SKIBIŃSKI ${ }^{1}$, PaUlina PRUSZKOWSKA-PRZYBYLSKA ${ }^{2}$

${ }^{1}$ Microbiology Student, ${ }^{2}$ Department of Anthropology, Faculty of Biology and Environmental Protection, University of Lodz, 12/16 Banacha St., 90-237 Lodz, E-mail: jk.skibinski@gmail.com, paulina.pruszkowska@biol.uni.lodz.pl

RELATIONSHIP BETWEEN VITAMIN D LEVEL AND AMOUNT OF BODY FAT IN HUMANS

Summary

Vitamin D3, apart from maintaining calcium and phosphate homeostasis, also has a significant influence, among others, on: the immune system, the muscular system or the circulatory system. Due to the presence of vitamin D receptors in many cells of the body, its multidirectional action is observed. Improper diet and lack of exposure to sunlight can lead to vitamin D deficiencies and promote the development of e.g. osteoporosis and rickets in children. Recent studies have shown that changes in vitamin D levels can affect the formation of metabolic diseases such as type I diabetes and lead to the development of overweight and obesity. In people with lowered levels of vitamin D occurrence of increased body weight is observed, which may be related to the hypothesis of the so-called postponing vitamin $\mathrm{D}$ in excessive amount of adipose tissue. On the other hand, there are reports that vitamin $\mathrm{D}$ reduces the amount of adipose tissue. More studies should be conducted to verify the molecular basis of the correlation of the influence of vitamin $\mathrm{D}$ concentration on the phenomenon of overweight and obesity.

Key words: BMI, body composition, obesity, VDR receptor, vitamin D 